\title{
Gerontology And Its Implications For Adult Education
}

\author{
Olajide, O. E. PhD \\ Ayantunji, Mojirade M. M.Ed \\ Department of Adult Education, University of Ibadan, Ibadan
}

doi: 10.19044/esj.2016.v12n13p321 URL:http://dx.doi.org/10.19044/esj.2016.v12n13p321

\begin{abstract}
The study of the elderly is a recent field of study and as such, has not been given its proper place in the human society. The elders or the retired workforce are in most cases regarded as people who have exhausted all their potentials of life during their services at their various places of work. They can no longer make meaningful contributions to the development of the society. This paper however, takes the position that adult education has a role to play in making people understand and appreciate the fact that the elderly or retired elderly people can still contribute meaningfully to the betterment of the human society. They should as well appreciate the message coded in gerontology. This paper explains the concept of ageing and its perspectives, gerontology and its implications to adult education. This paper concluded that adult education could be used in reducing the challenges faced by the elderly people by providing them with appropriate programmes of guidance and also proper counselling that will help in adjusting and assisting them to cope with the declining functions of the organ of the body and contribute meaningfully to improve the society.
\end{abstract}

Keywords: Gerontology, Elderly, Aging process and Adult Education

\section{Introduction}

Most people are frightened or afraid and not comfortable to hear that they are ageing or growing old. This is simply because it tends to suggest advancement in age, decline in the function of the organs of the body, and loss of flexibility, decline in hearing, vision, and lessen of muscular strength, flexibility of the skin and blood vessels, appearance of wrinkles on the skin and so on. It is a process that is inevitable a known fact that the process of maturation and ageing in living organisms (human beings) because life cycle continues and is not reversible until death comes. Ageing, should be conceived as a natural stage of development which comes when it should 
come. Ageing occur as a result of the cessation of cell division that takes place in human beings.

Today, ageing and anti-ageing have become a global phenomenon and the endless struggle against becoming old, the refusal to accept changes in the body and the millions of money spent on cosmetic and plastic surgery, the elderly people dressing like a young adolescent now are days pointed to the fact that nobody wants to get old. However, ageing just like death, is inevitable. No matter how one try to conceal it, it will definitely manifest with time. The ageing process goes beyond biological change. It includes physical, mental, social, and intellectual decline. All these negative indicators which show decline in the functions of body organs due to ageing make the adult individual feel uncomfortable to be associated with ageing. This feeling affects the adult person psychologically (Osunde \& Obiunu, 2005).

The elderly population (the retired people whether from formal or informal sector that is, people who cease from work due to old age) need relevant adult education programmes to enable them adjust and cope with changing and challenging conditions of their lives and in order to feel they are still relevant in the society where they belong. The adult education programmes should be able to motivate the elderly person at this period of life and to have the feeling that he/she can still learn and acquire knowledge in order to continue to exist comfortably and flourish in the society even during this old age period. For an elderly person to say that he/she is too old to learn makes him/her shuns social responsibilities as active members of the society and loses the will to live (Osunde \& Obiunu, 2005)

\section{Ageing Process}

The ageing process can be viewed from three major perspectives namely: biological, sociological and psychological ageing.

- Biological Ageing: This is usually associated with decline in the regulation and proper functioning of the vital organs of the body. However, not all people experience decreased organ function in the same proportion. Some individuals have healthier hearts at age 80 than others do at age 60 .

- $\quad$ Sociological Ageing: This is usually how a person relates with others in the society. In sociological ageing, personal or attitude and interaction within the community are used to assess a person's maturation and ageing. As a person ages socially, he/she calculates his/her utterances, limits the use of vulgar language, prunes relationship to mature friends, changes his/her mode of dressing, reduces nocturnal clubs. As a person ages socially, he/she tends to be guided by the norms of the society to which the person belongs.

- Psychological Ageing: Jegede (2003) stated that the indices of psychological ageing include feelings, motivation, memory, emotions, 
experiences and self-identity. For instance, people who had intention of travelling abroad may decide to jettison the idea and contribute to the growth of their own economy. Psychological ageing is heterogeneous and continuous as an individual passes through life. Cavanaught (1993) in Osunde and Obiunu (2005) divided ageing into three namely: the primary ageing, the secondary ageing and the tertiary ageing.

i. The Primary Ageing: Primary ageing is considered as the normal process which has nothing to do with illness. It simply involves changes in the biological, social and psychological domains. These occur due to tearing and wearing of vital organs of the body.

ii. The Secondary Ageing: This process is associated with different kinds of terminal illness which prevent normal functioning of the individual.

iii. The Tertiary Ageing: This occurs when there are loses brought about by death or disasters like war(s) on a family member or close friends that could lead to a gradual decline in the proper functioning of the individual.

\section{Gerontology}

Gerontology is derived from two Greek words "geron” which means "old man" and "logos" which means "discourse" or "study". Gerontology is the study of the phenomenon of old age. It is the study of the social psychological and biological aspects of ageing in an adult person. Gerontology is distinguished from geriatrics which is the branch of medicine that studies the diseases and care of the elderly person. The elderly adult deserves intensive medical attention as he continues to grow old.

The Oxford Dictionary defined gerontology as the study of ageing. The new Websters Dictionary of English Language (1994) edition, defines gerontology as a study of the phenomenon of old age. Also, the encyclopaedia on ageing (volume 2, 297-298) defined gerontology as the scientific study of ageing and older population. As the adult advances in age, the need for gerontology becomes necessary. Contemporary gerontology concerns itself with the ageing population. Considering the above definitions and explanations, gerontology encompasses the following:

a. $\quad$ Studying the physical, mental and social changes in elderly people as they age.

b. Investigating the ageing process itself (bio-gerontology).

c. Investigating the interface of normal ageing and age related diseases (geo-science).

d. Investigating the effects of our ageing population on our society; including the fiscal effects of pensions, entitlements, life and health insurance and retirement planning. 
e. Applying knowledge to policies and programmes; including a macroscopic perspective that is (running a nursing home).

These five scopes of gerontology can simply be referred to as multidisciplinary. This is so because there are a number of sub-fields in it, as well as psychology and sociology. The field of gerontology is relatively a late developed field of study. This simply means it is a recent field of study. This made it possible for it to lack structural and institutional support required. However, the huge increase in the elderly population in the recent times due to an improvement medical care generally made gerontology to become most rapidly growing field of study and a well-paid field for many all over the world. Gerontology has about four branches

\section{Branches of Gerontology}

Therefore, the following are the branches of gerontology which are embedded in its scope discussed above.

i. Bio-gerontology: This is a sub-field of gerontology that studies the biological process of ageing. It is composed of the inter-disciplinary research on biological ageing, causes, effects and mechanisms in order to better understand human senescence. Some bio-gerontologists like Leonard Hayflick, have worked to show that aging is a biological process that one is far from controlling. These gerontologists are also known as conservative bio-gerontologists. They have predicted that the life expectancy figures will peak at about the age of 85 (88 for females and 52 for males). Although these figures are not static this may continue to rise or decrease.

ii. Bio-medical gerontology: This is also known as experimental gerontology or life extension. Life extension is a sub discipline of biogerontology that endeavours to slow, prevent and even reverse ageing in both humans and animals by curing age-related diseases and showing the underlying processes of ageing. Some bio-gerontologists are at intermediate position, emphasizing the studying of the ageing process as a means of mitigating ageing-associated diseases. The gerontologists claim that maximum life cannot be altered.

iii. Medical gerontology: This branch of gerontology studies the biological causes and effects of ageing, medical and bio-gerontology is considered by many scientists to be the most important frontier in ageing research (Gracia, 2010).

iv. Social gerontology: This is a multi-disciplinary sub-field of gerontology that specialises in studying and working with elderly people. Social gerontologists are responsible for educating, researching and advancing the broader causes of ageing in elderly people by giving informative presentations, publishing books and articles that concerns the 
ageing population, producing relevant films and television programmes and producing new graduates in colleges and universities.

\section{Challenges and Implications of Gerontology to Adult Education}

UNESCO (1976) as cited in Nzeneri (2010) gave a generally acceptable definition to adult education as:

"the entire body of organized educational process whatever the content, level and method, formal or otherwise, whether they prolong or replace initial education in schools, colleges and universities as well as apprenticeship, whereby persons regarded as adults by the society to which they belong develop their abilities, enrich their knowledge, improve their technical or professional qualifications and bring about changes in their attitude and behaviour in the two fold perspectives of full personal development and participation in balanced and independent social, economic and cultural development".

The above definition is broad and encompassing in the sense that it does not only define adult education but also defines its content and scope. Eheazu (1998) observes that adult education in recent times has been misconceived to mean night school by many who lacked understanding of its meaning and nuances. This misconception poses as a very big challenge to adult education practitioners. In his effort to clarify this misconception, Eheazu (1998) defines it as "some specific functional training/vocational programmes required by adults (who now constitute the illiterate, unskilled, semi-skilled or semi-professional labour force) to remedy not only their educational deficiencies but also meet the needs of their various occupations whether as farmers, artisans or employees of corporate/private organizations". He further defined adult education as "any form of alternative education that would re-orientate the people and modify their attitudes in order that they embrace new and progressive ways and actions that would improve their income, living standard and contributions to societal development as well as bring about in them desired changes in their behaviour".

The challenge of poor public perception of adult education as night school as noted by Eheazu (1998) is considered as a serious challenge to adult education in Nigeria (Onyenemezu, 2012). However, it is a known fact that it is not only the individual ageing adults (elderly people) that are challenged by ageing problems but also the adult education practitioners, policy makers and the entire society (Onyenemezu, 2012). Hilgard (1977) and Ukpong (2000) noted that declining in physical strength tend to limit ones activities and debilitating illness which can make individual adults feel demoralized and helpless in the programme. The elderly people are now 
faced with challenging situations of retirement, more idle hours and less income which is likely to lead to poor self-concept and lower self-esteem which is illness of its own. These challenges required adult education for people (both the older adults and the younger ones) to be consciencetised about the roles adult education can play in their present situation(s).

Furthermore, Freire (1970) perceived adult education as "consciencetisation" which involves liberal education, extension and mass education, aesthetic, moral and cultural education programmes. Elderly people should not be treated the same way the younger ones should be treated, but rather they should be treated differently if their interest and enthusiasm for learning are to be motivated and sustained to enable them adapt or adjust to their current challenges of life and any coping adult education programme designed for them (Nzeneri 2000). Adult education is concerned not with preparing people for life, but rather with helping or assisting elderly at the stage of life to live more successfully and flourish as useful and acceptable members of the society and contribute meaningfully to the development of the society even during old age period (Fasokun, 2006; Onyenemezu, 2012).

More so, Adult education through its teaching helps the elderly to be able to manage the remaining years of their life endeavours more comfortably and joyfully in order to flourish throughout life time. The elderly requires awareness and coping programmes of adult education to enable them adapt and or adjust to their current situation of life. Obviously, there are life challenges to the ageing population like health problems, functional impairment, social and economic problems. The elderly facing these challenges require proper adult education programmes that will provide them with appropriate guidance and counselling services which will assist in coping with the declining functioning of the organs of the body. According to Olowookere (2003) it is necessary to improve quality of life and prevent or reduce dependency in an ageing population. Increasing age is associated with increasing risk of disability for example, hearing and vision. Ageing is associated with loss of bone tissues, reduction in muscle mass, reduction in respiratory functions, decline in cognitive functioning, high blood pressure and muscular degeneration which predisposes to conditions such as hear diseases, dementia, and blindness.

Physical challenges of the aged are experienced both internally and externally. Internal changes includes decline in functions of the bones, muscles, cells, heart and brain, while the external challenges are obviously observed in the face or body appearances. Wrinkles on the face and skin, hair colour changes from black to grey and so on. The challenges and changes that take place in human beings are progressive in childhood and 
adolescence periods and regressive or declining in adulthood (Nzeneri, 2000).

According to Ibeh (2001), statistics show that within the ages of 24 to 32 , the human body reaches its maximum size and strength and these are influenced by the amount of nutrient, rest, stress, and exercise and health conditions. This period is the time the body maintains a balance between the building of body tissues and their wearing down. The process of ageing begins when the rate at which more cells die are more than the rate at which they are produced or replaced. Hence between the ages of 32 and 45; the tissues of the body experience reduction in elasticity (Ibeh, 2001).

\section{Conclusion}

Adult education attempts to minimize the ageing challenges of the adults by providing them with programmes of appropriate guidance and counselling that will assist them cope with the declining functioning of the organs of the body. One of the basic assumptions of adult education is the belief in the adaptability and educability of human beings irrespective of their age, socio-economic and political responsibilities (Akinpelu, 1981). Human nature is not static but dynamic, hence adults at whatever age can still learn for adaptability and being relevant in the society. The elderly people are confronted with a lot of challenges ranging from physical, psychological, social and declining functions of the body due to ageing which is inevitable and irreversible.

These challenges could be overcome by organising adult education programmes which will help the elderly people to see ageing as a normal and natural phenomenon in the human life cycle. Gerontology and adult education should be seen as complements in taking care of the plight of the elderly or elderly retired workforce from both formal and in-formal sectors of the economy. These educational programmes should provide help, guidance and counselling suitable for proper adjustment, coping mechanisms during later part of their life and improvements of the aged or retired adults in their various societies.

\section{References}

Akinpelu, J.A. 1981. Philosophy of Adult Education in Bown, L. and Okedara, J.T. (eds.), An Introduction to the Study of Adult Education. Ibadan, Ibadan University Press Ltd.

Cavanaught, J.C. 1993. Adult development and Ageing (2nd Ed.). Pacific California: Coles Publishers.

Eheazu, B.A. 1998. The right to Learn: Relevance of adult education. University of Port Harcourt Inaugural Lecture Series No. 20.

Encyclopedia of Ageing 1949. (2) 297-298. 
Fasokun, T. 2006. NNCAE and the Challenges of Professionalizing adult education delivery in Nigeria: Emerging issues. Annual Conference, Calabar Nigeria Nov. 27 - Dec. 1.

Freire, P. 1970. Pedagogy of the oppressed. Australia: Pengium books Ltd.

Gracia, R. 2010. Biogerontology. Accessed August 14, 2015 from http://www.g<wl.orgwikipedia.com.

Hilgard, E. 1977. Theories of Learning. New York: Century-Grofts. Ibeh, A.E. 2001. Psychology of education, childhood, adolescence and adulthood in teaching-learning transaction. Port Harcourt CAPIIC Publishers.

Jegede, S. 2003. The adult learner: A psycho-social analysis. Lagos: University of Lagos Press.

New Oxford Dictionary. 2007. New Websters Dictionary of English.

Nzeneri, I.S. 2000. The role of adult education in mobilizing the retired in Port Harcourt towards proper adjustment: Nigerian Journal of Empirical Studies in Psychology and Education (NJESPE) 1(2) pp 96- 101.

Nzeneri, I.S. 2008. Handbook on adult education: Principles and Practices (new ed.). Uyo: Abigab Associates.

Olowookere, J. 2003. Ageing and the keys to longevity. Ibadan: Triumph Providential Publishers.

Onyenemezu, E.C. 2012. Adult education and the challenges of the 21st century in Nigeria. Journal of Education and Practice, 3(5) pp 1-6.

Osunde, A. U. and Obiunu, J. 2005. Education for the aged: Some imperatives for effective programme development and implementation. Nigerian Journal of Adult and Lifelong Learning. 1(2) pp 1-10.

Ukpong, E.M. 2000. The psychology of adult learning. Port Harcourt: Double Diamond Publishers.

Other Website Links are:

Ageing Status: http://www.ageingstatus.gov/ageingstatusdomet/ mainsite/Data 2008

http://www.gsw/.org/wikipedia.com 